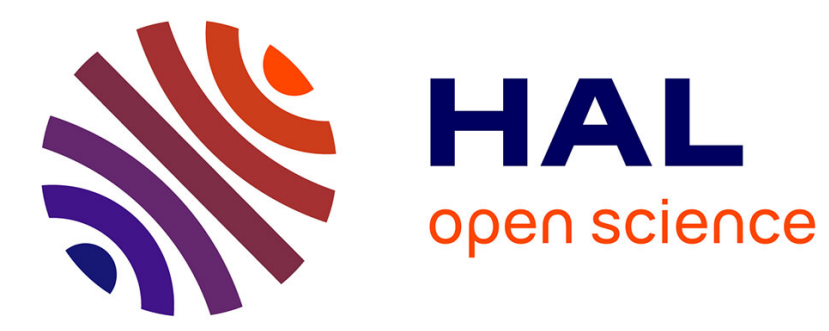

\title{
MCF-7 breast carcinoma cells do not express caspase-3
}

Reiner U. Jänicke

\section{To cite this version:}

Reiner U. Jänicke. MCF-7 breast carcinoma cells do not express caspase-3. Breast Cancer Research and Treatment, 2008, 117 (1), pp.219-221. 10.1007/s10549-008-0217-9 . hal-00486600

\section{HAL Id: hal-00486600 https://hal.science/hal-00486600}

Submitted on 26 May 2010

HAL is a multi-disciplinary open access archive for the deposit and dissemination of scientific research documents, whether they are published or not. The documents may come from teaching and research institutions in France or abroad, or from public or private research centers.
L'archive ouverte pluridisciplinaire HAL, est destinée au dépôt et à la diffusion de documents scientifiques de niveau recherche, publiés ou non, émanant des établissements d'enseignement et de recherche français ou étrangers, des laboratoires publics ou privés. 


\title{
MCF-7 breast carcinoma cells do not express caspase-3
}

\author{
Reiner U. Jänicke
}

Published online: 14 October 2008

(C) Springer Science+Business Media, LLC. 2008

Apoptosis, a fundamental process essential for normal tissue homeostasis and development, is closely associated with the activation of a class of aspartate-specific cysteinedependent proteases, called caspases, that lead to the demise of the cell via limited proteolysis of a multitude of cellular substrates [1,2]. Caspases are expressed as inactive zymogens that become activated upon cleavage by other caspases in a so-called caspase activation cascade, or by mere oligomerization instigated by the formation of large multi-protein complexes such as the death-inducing signaling complex (DISC) or the apoptosome [3, 4]. Whereas DISC formation occurs via the so-called extrinsic death pathway that is instigated by activation of members of the death receptor family such as CD95, tumor necrosis factor receptor (TNF-R) or the receptors of the TNF-Rrelated apoptosis-inducing ligand (TRAIL), the apoptosome is formed following activation of mitochondria and is hence termed the intrinsic or mitochondrial death pathway. Based on their order in cell death pathways, caspases can be divided into initiator (caspase-2, -8, -9, and -10) and effector (caspase-3, -6, and -7) caspases. Among them, caspase-3, a member of the latter group, is absolutely crucial for apoptosis induction, as this enzyme is not only activated downstream of both the extrinsic and intrinsic death pathway, it is also responsible for the cleavage of the majority of substrates known so far $[1,5]$. More importantly, with the proteolysis of discrete substrates, caspase- 3 evokes some of the typical morphological and biochemical alterations associated with apoptosis. For instance, whereas

R. U. Jänicke ( $\square)$

Laboratory of Molecular Radiooncology, Clinic and Policlinic for Radiation Therapy and Radiooncology, University of Düsseldorf, Universitätsstrasse 1, 40225 Düsseldorf, Germany e-mail: Janicke@uni-duesseldorf.de the caspase-3-mediated cleavages of $\alpha$-fodrin, gelsolin, rho-associated kinase-1 (ROCK-1) and p21-activated kinase 2 (PAK2) contribute to membrane blebbing, cleavage of the inhibitor of the caspase-activated DNase (ICAD) leads to the typical DNA fragmentation pattern observed in apoptosis [1]. Furthermore, with the cleavagemediated activation of the calcium-independent phospholipase A2 and subsequent production of the chemotactic phospholipid lysophosphatidylcholine, caspase- 3 appears to be also responsible for the generation of so-called "eatme" signals that induce migration of phagocytes to the site of apoptotic cell death [6]. Thus, caspase- 3 not only instigates and pursues the demise of a cell, but, in addition, makes sure that the corpse is properly disposed, a function crucial for avoiding inflammatory processes.

Hence, determination of the processing and activation of caspase- 3 are common means to assess apoptotic signal transduction pathways in numerous cell lines of varying origin. Curiously, several reports still claim the presence of caspase-3 in the breast carcinoma cell line MCF-7 in which this enzyme is supposed to contribute to apoptosis signaling [7-15]. This was not only demonstrated indirectly via fluorometric assay systems measuring caspase-3-like activities-that might be also elicited by the closely related caspase-7-but by Western blotting analyses demonstrating directly the presence of this protease in MCF-7 cells. However, in addition to the lack of caspase-10 [16], an initiator caspase in the extrinsic death pathway, MCF-7 cells do also not express caspase-3 [17]. Ten years ago, we demonstrated unambiguously that the lack of caspase- 3 in these cells is caused by a 47-base pair deletion within exon 3 of the CASP3 gene resulting in the skipping of this exon during premRNA splicing and introduction of a premature stop codon at position 42 that completely abrogates translation of the CASP-3 mRNA [17]. Although caspase-3-deficient MCF-7 
cells are still sensitive to cell death induction by several stimuli including TNF, staurosporine $[17,18]$ and various DNA damaging agents $[19,20]$, death of these cells occurs in the absence of DNA fragmentation. In addition, the distinct morphological features typical of apoptotic cells such as shrinkage and blebbing are also not evident in caspase-3deficient MCF-7 cells. As introduction of caspase-3 restored all of these events, our results - and also those of many other laboratories-clearly showed that this protease is crucial for these typical biochemical and morphological changes of cells undergoing apoptosis.

Although caspase-7 might compensate under certain circumstances for the lack of caspase-3, it is well appreciated that the executioner caspases 3,6 and 7 perform distinct, non-redundant roles during the demolition phase of apoptosis [21]. In addition, it was shown that caspase-3 is the primary activator of apoptotic (low molecular) DNA fragmentation via cleavage-mediated inhibition of ICAD [22]. Thus, it is puzzling that caspase-3-deficient MCF-7 cells exhibit DNA fragmentation and other apoptotic characteristics following cell death induction as described [7-15]. While it is still possible that caspase-3-deficient MCF-7 cells display high molecular weight DNA fragmentation that might be occasionally mistaken for the typical apoptotic DNA fragmentation, the detection of a caspase- 3 protein in MCF-7 cells [7, 8, 11, 13-15] with a partially deleted $C A S P$ 3 gene is cause for concern. Such discrepant findings may be partially explained by the use of inappropriate antibodies that cross-react with other caspase-3-unrelated proteins in cellular extracts, a phenomenon we have also observed previously (unpublished data). Alternatively, as there are several variants of MCF-7 cells around, the examined cultures might not contain the original MCF-7 cell line, and a karyotyp analysis to clarify this issue would be appropriate. Nevertheless, similar to our recent note of caution with regard to the presence of caspase-10 in the mouse [23], this letter should make a general readership aware of the fact that the original MCF-7 breast cancer line that can be obtained from the American Tissue Type Culture Collection (ATCC) does not express the caspase-3 protein. Hopefully, this misconception can be avoided in the future.

Acknowledgment This work was supported by the Collaborative Research Center "Extrinsic Ageing" funded by the Deutsche Forschungsgemeinschaft (SFB 728/B1).

\section{References}

1. Fischer U, Jänicke RU, Schulze-Osthoff K (2003) Many cuts to ruin: a comprehensive update of caspase substrates. Cell Death Differ 10:76-100. doi:10.1038/sj.cdd.4401160

2. Fuentes-Prior P, Salvesen GS (2004) The protein structures that shape caspase activity, specificity, activation and inhibition. Biochem J 384:201-232. doi:10.1042/BJ20041142
3. Kroemer G (2003) Mitochondrial control of apoptosis: an introduction. Biochem Biophys Res Commun 304:433-435. doi: 10.1016/S0006-291X(03)00614-4

4. Lavrik I, Golks A, Krammer PH (2005) Death receptor signaling. J Cell Sci 118:265-267. doi:10.1242/jcs.01610

5. Porter AG, Jänicke RU (1999) Emerging roles of caspase-3 in apoptosis. Cell Death Differ 6:99-104. doi:10.1038/sj.cdd. 4400476

6. Lauber K, Bohn E, Kröber SM, Xiao YJ, Blumenthal SG, Lindemann RK, Marini P, Wiedig C, Zobywalski A, Baksh S, Xu Y, Autenrieth IB, Schulze-Osthoff K, Belka C, Stuhler G, Wesselborg S (2003) Apoptotic cells induce migration of phagocytes via caspase-3-mediated release of a lipid attraction signal. Cell 113:717-730. doi:10.1016/S0092-8674(03)00422-7

7. Wang R, Wang X, Li B, Lin F, Dong K, Gao P, Zhang H-Z (2008) Tumor-specific adenovirus-mediated Puma gene transfer using the survivin promoter enhances radiosensitivity of breast cancer cells in vitro and in vivo. Breast Cancer Res Treat [Epub ahead of print] PMID: 18791823

8. Yeruva L, Abiodun E, Carper SW (2008) Methyl jasmonate decreases membrane fluidity and induces apoptosis through tumor necrosis factor receptor 1 in breast cancer cells. Anticancer Drugs 19:766-776. doi:10.1097/CAD.0b013e32830b5894

9. Nizamutdinova IT, Lee GW, Son KH, Jeon SJ, Kang SS, Kim YS, Lee JH, Seo HG, Chang KC, Kim HJ (2008) Tanshione I effectively induces apoptosis in estrogen receptor-positive (MCF7) and estrogen receptor-negative (MDA-MB-231) breast cancer cells. Int J Oncol 33:485-491

10. Kumar A, D'Souza SS, Gaonkar SL, Rai KML, Salimath BP (2008) Growth inhibition and induction of apoptosis in MCF-7 breast cancer cells by a new series of substituted-1,3,4-oxadiazole derivatives. Invest New Drugs 26:425-435. doi:10.1007/s10637008-9116-5

11. Cui Q, Yu J-h, Wu J-n, Tashiro S-i, Onodera S, Minami M, Ikejima T (2007) p53-mediated cell cycle arrest and apoptosis through a caspase-3-independent, but caspase-9-dependent pathway in oridonin-treated MCF-7 human breast cancer cells. Acta Pharmacol Sin 28:1057-1066. doi:10.1111/j.1745-7254.2007. 00588.x

12. Hsuuw YD, Chan WH (2007) Epigallocatechin gallate dosedependently induces apoptosis or necrosis in human MCF-7 cells. Ann N Y Acad Sci 1095:428-440. doi:10.1196/annals.1397.046

13. Zhang GP, Lu YY, Lv JC, Ou HJ (2006) Effect of ursolic acid on caspase-3 and PARP expression of human MCF-7 cells. Zhongguo Zhong Yao Za Zhi 31:141-144

14. Yang HL, Chen CS, Chang WH, Lu FJ, Lai YC, Chen CC, Hseu TH, Kuo CT, Hseu YC (2006) Growth inhibition and induction of apoptosis in MCF-7 breast cancer cells by Antrodia camphorata. Cancer Lett 23:215-227. doi:10.1016/j.canlet.2005.02.004

15. Chen JS, Konopleva M, Andreeff M, Multani AS, Pathak S, Mehta K (2004) Drug-resistant breast carcinoma (MCF-7) cells are paradoxically sensitive to apoptosis. J Cell Physiol 200:223234. doi: $10.1002 / j \mathrm{cp} .20014$

16. Engels IH, Totzke G, Fischer U, Schulze-Osthoff K, Jänicke RU (2005) Caspase-10 sensitizes breast carcinoma cells to TRAILinduced but not tumor necrosis factor-induced apoptosis in a caspase-3-dependent manner. Mol Cell Biol 25:2808-2818. doi: 10.1128/MCB.25.7.2808-2818.2005

17. Jänicke RU, Sprengart ML, Wati MR, Porter AG (1998) Caspase3 is required for DNA fragmentation and morphological changes associated with apoptosis. J Biol Chem 273:9357-9360. doi: 10.1074/jbc.273.16.9357

18. Jänicke RU, Ng P, Sprengart ML, Porter AG (1998) Caspase-3 is required for alpha-fodrin cleavage but dispensable for cleavage of other death substrates in apoptosis. J Biol Chem 273:1554015545. doi:10.1074/jbc.273.25.15540 
19. Jänicke RU, Engels IH, Dunkern T, Kaina B, Schulze-Osthoff K, Porter AG (2001) Ionizing radiation but not anticancer drugs causes cell cycle arrest and failure to activate the mitochondrial death pathway in MCF-7 breast carcinoma cells. Oncogene 20:5043-5053. doi:10.1038/sj.onc. 1204659

20. Essmann F, Engels IH, Totzke G, Schulze-Osthoff K, Jänicke RU (2004) Apoptosis resistance of MCF-7 breast carcinoma cells to ionizing radiation is independent of p53 and cell cycle control but caused by the lack of caspase- 3 and a caffeine-inhibitable event. Cancer Res 64:7065-7072. doi:10.1158/0008-5472.CAN-04-1082

21. Slee EA, Adrain C, Martin SJ (2001) Executioner caspase-3, -6, and -7 perform distinct, non-redundant roles during the demolition phase of apoptosis. J Biol Chem 276:7320-7326. doi: 10.1074/jbc.M008363200

22. Wolf BB, Schuler M, Echeverri F, Green DR (1999) Caspase-3 is the primary activator of apoptotic DNA fragmentation via DNA fragmentation factor-45/inhibitor of caspase-activated DNase inactivation. J Biol Chem 274:30651-30656. doi:10.1074/jbc. 274.43.30651

23. Jänicke RU, Sohn D, Totzke G, Schulze-Osthoff K (2006) Caspase-10 in mouse or not? Science 312:1874. doi:10.1126/science. $312.5782 .1874 \mathrm{a}$ 